\title{
Organizational Innovativeness: Factors that Drive Innovations in Social Enterprises in Serbia
}

DOI: 10.7595/management.fon.2019.0014

\begin{abstract}
:
Research Question: This paper explores factors that drive innovativeness of social enterprises in Serbia. Motivation: Social enterprises are gaining importance on the global scale, being recognized for their potential to respond to both economic and social challenges, attract capital and generate income in non-traditional ways. Innovativeness comes at the heart of their abilities to achieve their goals. This research is motivated by the idea to understand which factors influence innovativeness in Serbian social enterprises, and to compare these results with the pool of 11 European countries. Identification of the factors that make the difference between social enterprises that are innovative and the ones that are not, provides a chance for business owners/managers, as well as for social policies creators, to affect these factors and thus influence the boost of innovativeness and, consequently, success of socially oriented enterprises in Serbia. Additionally, building on results of a research conducted in 11 European countries, the authors' idea is to perform a cross analysis of identified innovation factors in social enterprises in Serbia with previously obtained aggregated results. Idea: This paper was driven by the idea to identify the factors that make a difference in innovative behaviour of social enterprises. Data: The analysis was conducted using responses from on-line survey of 69 Serbian enterprises. We compared these answers to those of 837 social enterprises obtained via the same online surveys from 11 European countries, including Serbia. Tools: A statistical analysis was performed (using t-test for testing equality of means, z-test for testing equality of proportion, hi-square test, Fisher's exact test and some nonparametric tests to confirm the results obtained using parametric tests). The same tests were carried out on the data obtained from social enterprises in Serbia and on the data obtained from all 11 countries examined in order to draw conclusions about the same or different influence of certain factors on the innovativeness of social enterprises. Findings: We found that the awareness of their social mission, perception of innovation as an important factor, financing obtained via grant schemes and involvement of owners, board, customers and NGOs are the most important drivers of innovativeness in Serbian social enterprises. The European pool of explored SEs report additional factors influencing innovativeness, which did not appear important in the Serbian sample. Contribution: This paper contributes to the research of determinants of the innovativeness of social enterprises by bringing original field data from Serbia, and by providing comparison with the same pool factors examined in the sample of European countries.
\end{abstract}

Keywords: innovativeness, non-innovativeness, social enterprise, Serbia

JEL Classification: M10, M14, O31, O35

\section{Introduction}

Innovations have reached the forefront of interest in management and organization theory and practice for some time now. Defined as incremental or radical product and/or process transformations (Schumpeter, 1934), innovations include changes, (Betz, 1998) as well as transformation of business concept or paradigm on which business is founded (Guth and Ginsberg, 1990). Organizational innovativeness is seen as a necessary condition for long-term sustainability; many authors have discussed the importance of business innovation and have emphasized its positive contribution to profitability (Zahra, 1993), company growth (Thornhill, 2006), competitive advantages (Porter, 1985), organizational learning and development (GarciaMorales, Montes \& Jover, 2006), enhancement of company's intellectual capital residing in people (human capital), relationships (social capital), and systems (organizational capital) (Simsek and Heavy, 2011), team 
work within the company (Fay et al., 2015) and development of a strong network of relationships with external strategic constituents (Kandampully, 2002). On the people level, the innovation-driven strategy with its effects on the increase in flexibility and autonomy in the decision-making, reduces control by superiors and decreases work monotony, leading to a higher job satisfaction and employees' well-being (Bryson et al., 2009; Park et al., 2015).

Innovations are recognized as important not only for organizational economic performance, but for its social performance as well (Choi \& Majumdar, 2014; Lehner, \& Kansikas, 2012; Austin, Stevenson, \& WeiSkillern, 2006; Mulgan, G, 2006; Mumford \& Moertl, 2003; Leadbeater, 1997). Even if not initially inspired by social motives, development of a new product or service can affect improvement of living conditions of individuals or society in general (e.g., development of a new medicine), while technological innovations require engagement of different social actors or transformation of social structures with the goal of faster diffusion and adaptation (Sharra \& Nyssens, 2018). In that manner, every innovation includes a certain social aspect which comes as a consequence of finding new ways of transforming input to output that has a higher value for the consumer, owner or the environment and a wider social community. However, our knowledge about social innovations and innovativeness of social enterprises, factors that drive their development or effects they provide is still modest, though business practice and policy discourse both express the need for deeper research into this area (Zarkovic Rakic et al., 2017; Krstic, Aleksic Miric, \& Zarkovic, 2017; Aleksic Miric, \& Krstic, 2016; Sinclair, Mazzei, Baglioni, \& Roy, 2018; Alvord, Brown \& Letts, 2004). Recent research proves the importance and the necessity to further study this area. Thus, Bellucci examines the importance of innovation in some stages of the development of social enterprises, but also outlines the key challenges and barriers to their implementation (Bellucci et al., 2018). Similarly, while one group of authors explain the power and the role of the network of stakeholders to create social innovations and the sustainable business of socially oriented businesses (Hazenberg et al., 2018), another group of authors, by adopting a resource-based perspective, examine the role of market orientation and ICT competences in this process (Sanzo-Perez et al., 2015). Some research on this topic relates to identifying the characteristics and attitudes of the decisionmakers in the SE swith an aim to determine their relationship to fostering socially-oriented innovative activities (Gauthier et al., 2018; Testi et al., 2018). Policy discourse also points to the importance of social entrepreneurship and social innovation in a wider social and political context. According to OECD findings (OECD, 2016), economic and industrial innovation results in greater inequality, and social entrepreneurs and private sector representatives are expected to play a key role in fostering innovative social policy (During et al., 2018). Social innovations are not limited to newcomers only, but also have a very important role in the sustainability of already established systems (Fuchs, 2014) through the introduction of social intrapreneurship.The need for identifying the key factors of innovation in social enterprises in Serbia, as well as raising awareness about the importance of social entrepreneurship and social innovations in general, is a consequence of studies already conducted on other countries' examples (see Brandsen et al., 2016; Biggeri et al., 2018) in which further research is called for.

Social enterprises (SE) are usually seen as the key promoters of social innovation (Di Domenico, Haugh, \& Tracey, 2010). Being ambidextrous in their nature by simultaneously pursuing social and economic mission, social enterprises are focused on creation and implementation of innovative solutions so that they can meet this duality (Doherty, 2014; Pache \& Santos, 2012). On the one hand, social enterprises do their business on the profit-oriented company principles by focusing on long-term financial sustainability while, on the other hand, they pursue social goals as their primary founding reason. Understanding both goals is mostly dependent on continuous innovative endeavours of the enterprise (Jeraj et al, 2015; Zahra, Newey, \& Li, 2014; Renko, 2013; Gundry et al., 2011; Zahra, Gedajlovic, Neubaum, \& Shulman, 2009).

In this paper we explore the factors that influence innovativeness drivers in social enterprises in Serbia. By doing so, this paper contributes to the understanding of factors that influence innovativeness of social enterprises in Serbia, and provides comparison with the same pool of factors examined in the sample of European countries. The paper is structured as follows: Section 2 brings a theoretical review of the factors that drive organizational innovativeness, Section 3 outlines the methodology we used, Section 4 brings research results into focus and compares Serbian and European results. We end with summarizing the results and bringing implications from key comparisons.

\section{What Drives Organizational Innovativeness?}

The foundation for studying innovativeness in an organizational context was laid by Zaltman, Duncan and Holbek's book Innovations and Organizations (1973). How important innovation is for an organization was in particular highlighted by Clark (1987) who argues that "innovation should be at the centre of study of or- 
ganizations" instead of bureaucracy, structure and performance. In the critical review on organizational innovation literature, Wolfe (1994) identified three streams of research: (1) diffusion of innovation research that focuses on exploring the pattern of an innovation through a population of potential adopter organizations, (2) organizational innovativeness research that focuses on exploring what determines organizational innovativeness and (3) process theory research that addresses the issue of processes organizations go through in implementing innovation (Wolfe, 1994). The drivers of organizational innovativeness are mostly examined within the second and the third research area, as they are identified by Wolfe (1994). Damanpour and Gopalakrishnan (1998) differentiated that the origin of innovation can be within the organization, in which case innovation is generated via factors associated with internal organization, or from the outer world, when innovation is generated outside organizational borders. Following this line we systematize innovation drivers into four groups: external environment of the organization, macro-organizational factors, group (team)-level factors and people-related innovation drivers.

External environment. Frequent and unforeseeable changes in the environment are a critical source of uncertainty for a company. Therefore, entrepreneurs/enterprises try to improve current circumstances and treat volatile environments as opportunities for changes and improvements (Jensen, 2009); innovations appear as a result of these endeavours. This is confirmed by results of empirical studies that have found that, within a dynamic environment, the most successful enterprises are the ones distinguished by high levels of innovative behaviour (Zahra, 1993). The contrary also applies. If the company is doing business in stable and predictable environment, it gets less motivated to pursue innovative behaviour. According to Porter, competition is a specific element of external environment that contributes to innovations in a company, and in case a company today pays attention to its competitive environment, innovation becomes its key, and often, the only factor of success (Porter, 1985).

I addition to the drivers coming from external environment, numerous organizational factors also influence innovation generation. A number of research has focused on the influence the organizational structure has on innovativeness, applying a presumption that structural variables are a primary determinant of organizational innovativeness (Damanpour \& Gopalakrishnan, 1998; Kimberly \& Evanisko, 1981). Wolfe, in a review, (Wolfe, 1994) explains that criticism of this approach has mainly raised the issue of static and argues that innovativeness is a process, and that this process should be taken into account, as well as that not enough is known about how determinants of organizational innovation mutually interact. On the organizational level, the previously formed network of relationships with its stakeholders that actively participates in product improvement of products and processes or in design of new technological innovations (Hart \& Sharma, 2004).

Group (team) level innovation drivers are explored within the context of structure, climate, team processes, member characteristics, and the leadership style, which determine whether the innovative potential of the team is to be realized.

On the level of people involved (individual level), experience and education of managers and owners is among the most important innovation drivers. Since knowledge is a fundamental factor in creation of new technological solutions, as well as in adoption of existing solutions (Urbancova, 2013), many authors see owner/manager knowledge obtained through previous experience and education as a key factor for success of any organization (Koellinger, 2008). Additionally, innovative behaviour of companies is often attributed to personal satisfaction of employees, as well as to interpersonal relationships organizations. Thus, innovations are more common in companies where employees show a higher level of satisfaction with personal as well as professional aspects of their lives (Tu \& Hwang, 2013). On the other hand, benevolent relationships between employees are a firm basis for creation and distribution of knowledge, which is the main driving force behind innovations (Abrams et al., 2003).

\section{Methodology}

This paper is closely linked to the research that evaluated the same pool of factors in 11 European countries, including Serbia: Albania, Austria, Denmark, England, France, Germany, Italy, Poland, Serbia, Scotland and The Netherlands (in alphabetical order) as presented in Aleksic Miric, Petrovic \& Celikovic (2018). Both research works are based on the same dataset, but here we focus exclusively on results gained from Serbian respondents and refer to the EU results by comparing and contrasting our findings.

The data were gathered by online questionnaire that was sent by e-mail to the population of social enterprises. Respondents were owners or managers above the age of 18. The questionnaire consisted of several modules. The first three modules were designed to capture data on personal characteristics of the respon- 
dents (such as gender, age, education, previous experience in founding/managing a social enterprise, motivation etc.), as well as on general characteristics of the enterprise (such as its type, size according to the number of employees, ownership structure, year of establishment, sector of economic activity, sales turnover, etc.). The other modules were devoted to the following dimensions of social enterprises: access to financing, main challenges and constraints for social enterprises, the role of innovation during the life-cycle of the enterprise, the influence of different categories of stakeholders on the decision-making process of the enterprise and the social capital of entrepreneurs.

In the dataset, we had 90 enterprises from Serbia out of which 69 could be identified as innovative or noninnovative social enterprises. The decision made by researchers was to distinguish innovative form non-innovative SEs by defining innovative social enterprises (further marked as ISE) as organizations that used innovations in doing business within the last three years, namely those whose managers or owners responded positively ("yes") when answering the question "Has your organisation innovated in terms of products, process, finance, or marketing in the last 3 years?" when filling in the questionnaire. Opposite to this, SEs whose representatives responded negatively to the question above were classified as non-innovative SEs (further marked as NISE). As stated earlier, our motive was to determine which factors encourage social enterprises to behave in innovative way. Therefore, in our research, we focused on identifying factors that come from intra-organizational setting (micro and macro organizational factors) as well as those coming from external environment.

Table 1: Questions tested

\begin{tabular}{|c|c|}
\hline Factor & Question \\
\hline \multirow{7}{*}{ External environment } & $\begin{array}{l}\text { Is contributing to solving a social or environmental issue an objective of your } \\
\text { organization? }\end{array}$ \\
\hline & $\begin{array}{l}\text { Which of the following sources of funding are available for social enterprises in } \\
\text { your country? }\end{array}$ \\
\hline & Where did your organization get the funds to start its activity? \\
\hline & $\begin{array}{l}\text { Which funds do you actually use in your activity? Do you use bank loans, } \\
\text { grants from projects, personal savings, donations/fundraising, crowdfunding, } \\
\text { microcredit, regulated market (e.g., insurances), social investment or private } \\
\text { investment for activity? }\end{array}$ \\
\hline & Did you innovate in response to a change in your external environment? \\
\hline & $\begin{array}{l}\text { Please describe the degree to which the following categories of stakeholder } \\
\text { influence the decision making in your organization }(5=\text { high influence; } 1=\text { no } \\
\text { influence). }\end{array}$ \\
\hline & What stakeholder engagement practices do you use: \\
\hline \multirow{3}{*}{$\begin{array}{l}\text { Organizational-level } \\
\text { factors }\end{array}$} & $\begin{array}{l}\text { Is it important for your organization to grow? (e.g., increase the number or } \\
\text { range of activities, recruit more employees, etc.?) }\end{array}$ \\
\hline & $\begin{array}{l}\text { How important was innovation in the start-up phase of your organization, i.e., } \\
\text { in terms of products, process, finance, or marketing? }\end{array}$ \\
\hline & How important are innovations in current phase? \\
\hline Group-level factors & $\begin{array}{l}\text { In my team people generally trust each other. } \\
\text { In my team people generally co-operate effectively. } \\
\text { I generally trust people in my team }{ }^{\star *} \text { I can generally co-operate with my team } \\
\text { members. } \\
\text { The enterprise has a large network of business relations. }\end{array}$ \\
\hline \multirow{7}{*}{$\begin{array}{l}\text { Individual-level } \\
\quad \text { factors }\end{array}$} & Does your organization employ paid staff? \\
\hline & Have you been involved in founding a social enterprise before this one? \\
\hline & Have you managed a social enterprise before this one? \\
\hline & What is your main motivation to work in/ found a Social Enterprise? \\
\hline & How satisfied are you with your professional life in general? \\
\hline & What is your highest education qualification? \\
\hline & Do you identify yourself as a person with severe disabilities? \\
\hline
\end{tabular}

In order to get an answer to the previously set research questions, a null hypothesis was tested to ensure that the specific factor (as questioned in Table 1) does not affect organizational innovativeness. The null hypothesis in metric data states that the average value in ISE is equal to the average value in NISE, while in the case of non-metric data it is stated that a certain proportion within ISE data is equal to the proportion within NISE dataset. The null hypothesis was tested for each individual factor. The result of a statistical test 
provides a realized $p$-value based on which we reject or not-reject the null hypothesis. When the $p$-value is less than the significance level $\alpha=0.05$, the null hypothesis is rejected, otherwise it is not rejected. In case that we do not reject the null hypothesis, the conclusion is that the factor does not affect the innovation, i.e., that there is no difference between the ISE and the NISE regarding the examined factor, which is marked with the sign "=". If the null hypothesis is rejected, we conclude that the factor influences innovation, i.e., that there is a statistically significant difference between the ISE and the NISE in terms of the investigated factor, which was marked with the sign " $\neq$ ".

Statistical analysis was performed using the t-test for testing equality of means, z-test for testing equality of proportion, hi-square test, Fisher's exact test and some nonparametric tests to confirm the results obtained using parametric tests. For numerical variables we used the t-test for testing equality of means between ISE and NISE. Questions that have been taken into analysis for this research follow the Likert item logics scale, like 1-Completely disagree, 2 -Disagree, 3-Neither agree or disagree, 4-Agree, 5-Completely agree. Such variables have been considered as metric variables while testing, and we applied the t-test. The results gained that way have also been checked by the application of non-parametric tests. The analysis has shown the same results. For making statistical inferences in the chapter we used $\alpha=0.05$. Therefore, we conclude that the inference is valid both in case when data are treated as metric or as non-metric ones.

\section{Research results}

As explained, we have gathered the data on personal characteristics of respondents, their experience, general characteristics of the enterprise, access to capital, challenges and constraints, the role of innovation, the influence of different stakeholders on decision-making processes, and the social capital of entrepreneurs. The whole list of explored factors, derived from the questions in, is provided in. Based on these data we investigated what factors influence innovativeness of social enterprises in Serbia. This section explains which of the explored factors have proved (by using statistical tests as described in the Methodology section) to influence innovativeness and in what manner.

Contribution to solving a social problem and innovativeness. Recognizing contribution to solving a social or environmental issue as organization's objective is reported to make a difference between innovative and non-innovative social enterprises. While both ISE and NISE report this as organizational objective, ISEs recognize it with statistically significant difference (Table 1).

Table 2: Contribution to solving a social problem and innovativeness comparisons of column proportions (Serbia)

\begin{tabular}{lccc}
\hline $\begin{array}{l}\text { Question/Factor } \\
\text { Is contributing to solving a social or environmental issue an objective }\end{array}$ & Yes & NISE \\
\cline { 3 - 4 } $\begin{array}{l}\text { of your organisation? } \\
\text { No }\end{array}$ & No of.9\% & $78.9 \%$ \\
\hline & No respondents & 48 & $21.1 \%$ \\
\hline
\end{tabular}

Innovation importance in different stages of the life cycle. In comparison with NISEs, ISEs value innovation higher (mean value 3.9), and they value the importance of innovation in the start-up phase as well as in the current one. That means that those SEs that innovate, consider innovation to be important in all phases of the organization's life cycle (Table 2).

Table 3: Innovation importance in different stages of life cycle - testing equality of means (Serbia)

\begin{tabular}{|c|c|c|c|c|}
\hline \multirow{2}{*}{ Questions/ Factors* } & \multirow{2}{*}{$\begin{array}{l}\text { Test } \\
\text { results }\end{array}$} & \multirow{2}{*}{$\begin{array}{c}\text { p- } \\
\text { value }\end{array}$} & \multicolumn{2}{|c|}{ Mean value } \\
\hline & & & ISE & NISE \\
\hline $\begin{array}{l}\text { How important was innovation in the start-up phase } \\
\text { of your organisation, i.e., in terms of products, } \\
\text { process, finance, or marketing? }\end{array}$ & $\neq$ & 0.003 & 3.90 & 2.85 \\
\hline
\end{tabular}

*offered responses: 1-Not at all satisfied/important, 2-Slightly satisfied/important, 3-Moderately satisfied/Neutral, 4-Very satisfied/important,

5 -Extremely satisfied/important.
No ISE $=49$ No NISE $=20$ 
Start-up funding and innovativeness. A source of funding (bank loans, grants from projects, personal savings, donations, fundraising, social investment, private investment) for starting the activity does not influence innovativeness in any case, except in cases the funds originated from grants. The same conclusion can be drawn about the source of financing at the time when the research was done - grants from projects in Serbia influence innovativeness of social enterprises in such a manner that those who have used grants from projects innovate more in the start-up phase, as well as in the current (Table 3).

Funding and innovativeness. We have tested the following sources of funding: bank loans, grants from projects, personal savings, donations, fundraising, social investment, and private investment and they do not influence innovativeness in SEs. The only funding type that is connected to innovativeness is the use of grants from projects to start the activity which they actually use from the activity.

Table 4: Funding and innovativeness - comparisons of column proportions (Serbia)

\begin{tabular}{|c|c|c|c|c|}
\hline \multirow{2}{*}{ Grants from projects } & \multirow{2}{*}{ Test results } & & \multicolumn{2}{|c|}{ Percent } \\
\hline & & & ISE & NISE \\
\hline \multirow{2}{*}{$\begin{array}{l}\text { Using grants from projects to start its } \\
\text { activity? }\end{array}$} & \multirow{2}{*}{$\neq$} & Yes & $38.8 \%$ & $10 \%$ \\
\hline & & No & $61.2 \%$ & $90 \%$ \\
\hline \multirow{2}{*}{$\begin{array}{l}\text { Using grants from projects for actual } \\
\text { activity }\end{array}$} & \multirow{2}{*}{$\neq$} & Yes & $49.0 \%$ & $20.0 \%$ \\
\hline & & No & $51.0 \%$ & $80.0 \%$ \\
\hline \multicolumn{3}{|c|}{ Number of respondents } & 49 & 20 \\
\hline
\end{tabular}

Influence of stakeholders and innovativeness. In innovative social enterprises, stakeholders such as Owner / Boards of Directors, Employees, Customers and users, Third Sector Organizations and NGOs and the Community have a greater impact on decision making than in the non-innovative ones (). Shareholders/ Investors, suppliers and state and public administration make no difference in influencing the average impact on decision making between innovative and non-innovative enterprises.

Table 5: Influence of stakeholders and innovativeness - testing equality of means (Serbia)

\begin{tabular}{|c|c|c|c|c|}
\hline $\begin{array}{l}\text { G.1) Degree to which stakeholders influence } \\
\text { the decision making in organisation ( } 5= \\
\text { high influence; } 1=\text { no influence) }\end{array}$ & $\begin{array}{c}\text { Test } \\
\text { results }\end{array}$ & $\begin{array}{c}\text { Type of } \\
\text { organisation }\end{array}$ & $\mathbf{N}$ & Mean \\
\hline \multirow{2}{*}{ Owner/Boards of directors } & \multirow{2}{*}{$\neq$} & ISE & 48 & 4.3542 \\
\hline & & NISE & 20 & 3.7000 \\
\hline \multirow{2}{*}{ Shareholders/Investors } & \multirow{2}{*}{$=$} & ISE & 48 & 2.5417 \\
\hline & & NISE & 20 & 2.3500 \\
\hline \multirow{2}{*}{ Employees } & \multirow{2}{*}{$\neq$} & ISE & 48 & 3.4583 \\
\hline & & NISE & 20 & 2.6000 \\
\hline \multirow{2}{*}{ Suppliers } & \multirow{2}{*}{$=$} & ISE & 48 & 2.2083 \\
\hline & & NISE & 20 & 2.2500 \\
\hline \multirow{2}{*}{ Customers and users* } & \multirow{2}{*}{$\neq$} & ISE & 48 & 3.5208 \\
\hline & & NISE & 20 & 2.9000 \\
\hline \multirow{2}{*}{ State and public administration } & \multirow{2}{*}{$=$} & ISE & 48 & 2.7292 \\
\hline & & NISE & 20 & 2.6000 \\
\hline \multirow{2}{*}{ Third sector organisations and NGOs } & \multirow{2}{*}{$\neq$} & ISE & 48 & 2.4375 \\
\hline & & NISE & 20 & 1.6000 \\
\hline \multirow{2}{*}{ Community } & \multirow{2}{*}{$\neq$} & ISE & 48 & 3.0417 \\
\hline & & NISE & 20 & 1.8500 \\
\hline
\end{tabular}

* By rule we apply alpha $5 \%$ with an exception in this case when alpha is $10 \%$ 
Stakeholder engagement practice and innovativeness. The type of stakeholder engagement practice was examined as well. We evaluated the influence of the following different practices of stakeholder involvement: dedicated telephone lines, public meetings, collection of feedback, surveys and evaluation of users' satisfaction, advisory groups, stakeholder involvement in the reporting of activities (e.g., sustainability reporting), membership of executive boards and social media. Innovative social enterprises are less likely to use collection of feedbacks, surveys and evaluation of users' satisfaction as stakeholders' engagement practices in comparison with non-innovative social enterprisers. When we analysed social media we saw that NISE used social media as stakeholders engagement practice in a statistically higher percent than ISE did ().

Table 6: Stakeholder engagement practice and innovativeness comparisons of column proportions (Serbia)

\begin{tabular}{|c|c|c|c|c|}
\hline \multirow{2}{*}{$\begin{array}{l}\text { What stakeholder engagement practices } \\
\text { do you use? }\end{array}$} & \multirow{2}{*}{$\begin{array}{l}\text { Test } \\
\text { results }\end{array}$} & & \multicolumn{2}{|c|}{ Type of organisation } \\
\hline & & & ISE & NISE \\
\hline \multirow{2}{*}{$\begin{array}{l}\text { Collection of feedback, surveys and } \\
\text { evaluation of users' satisfaction }\end{array}$} & \multirow{2}{*}{$\neq$} & Yes & $43.8 \%$ & $85.0 \%$ \\
\hline & & No & $56.3 \%$ & $15.0 \%$ \\
\hline \multirow{3}{*}{ Social media } & \multirow{2}{*}{$\neq$} & Yes & $60.4 \%$ & $90.0 \%$ \\
\hline & & No & $39.6 \%$ & $10.0 \%$ \\
\hline & \multicolumn{2}{|c|}{ Number of respondents } & 48 & 20 \\
\hline
\end{tabular}

Team characteristics and innovativeness. Our statistical analysis shows that team members cooperate well in both ISEs and NISE. However, trust levels are significantly higher among team members who work in ISEs than among those who work in NISEs. The cooperation level among team members is also higher in ISE compared to NISE. ISEs also appear to be more likely to develop diverse networks of business relations.

Table 7: Team characteristics and innovativeness - testing equality of means (Serbia)

\begin{tabular}{lllll}
\hline \multicolumn{1}{c}{ Statements* } & \multirow{2}{*}{ Test results } & \multicolumn{2}{c}{ p- } & \multicolumn{2}{c}{ Mean value } \\
& value & ISE & NISE \\
\hline In my team people generally trust each other & $\neq$ & 0.048 & 4.04 & 3.47 \\
\hline $\begin{array}{l}\text { In my team people generally co-operate } \\
\text { effectively }\end{array}$ & $=$ & 0.122 & 3.93 & 3.60 \\
\hline $\begin{array}{l}\text { I generally trust people in my team** } \\
\text { I can generally co-operate with my team }\end{array}$ & $\neq$ & 0.01 & 4.26 & 3.53 \\
\hline $\begin{array}{l}\text { members } \\
\text { business relations. }\end{array}$ & $\neq$ & 0.02 & 4.43 & 4.00 \\
\hline
\end{tabular}

* Offered answers to respondents: 1- Not at all, 2 - A little, 3 - Medium, 4 - Quite a lot, 5 - Completely. ** realized $\mathrm{p}=0.1$ when performed nonparametric test to verify results of t-test $* * *$ No ISE $=47$ No NISE $=15$

The section above analysed the factors that influence innovativeness of social enterprises in Serbia. In addition, we run the same analysis for the sample of 837 social enterprises from 11 European countries. Comparison of the results is provided in. That comparison shows that the European pool of explored SEs reports additional factors influencing innovativeness, which did not appear important in the Serbian sample. These are: availability of funding, innovativeness in response to a change in your external environment, orientation towards growth, having the paid staff, previous experience in founding/managing a social enterprise, motivation to work in/ found an SE, professional life satisfaction, education level and being disabled. If grouped as external environment factors, organizational factors, group-level factors and individual-level factors, results show the following.

Table 8 gives a summary of the individual impacts of the investigated factors on the organizational innovativeness in 11 European countries and Serbia. "Yes" in the column means that the factor explored influence innovativeness, while "No" means that the factor does not affect innovativeness. 
In addition to the above, the following factors have been tested: involvement in any economic activity (such as selling goods and services); independency of income from grants, donation, bequests, or benefactions; investing profits to fund core activities; opportunity of the respondents to decide/manage major issues in the enterprise (e.g., strategy, enterprise objectives, activities to be run, organization of team work, etc.); family history of entrepreneurship, gender of the respondents; and vocational education or training relevant for their current position. Analyses show that these factors do not influence innovativeness in 11 European countries nor in Serbia.

Table 8: Influence of particular factors on the innovativeness of social enterprises in Serbia and 11 European countries

\begin{tabular}{|c|c|c|c|}
\hline Factor & Factors & Serbia & $\begin{array}{c}11 \\
\text { European } \\
\text { countries }^{\star}\end{array}$ \\
\hline \multirow{7}{*}{$\begin{array}{c}\text { External } \\
\text { environment }\end{array}$} & Solving social or environmental issues & Yes & Yes \\
\hline & Availability of various sources of funding for SE & No & Yes \\
\hline & Using grants from projects to start the activity? & Yes & Yes \\
\hline & Using grants form projects for actual activity & Yes & Yes \\
\hline & $\begin{array}{l}\text { Innovative behaviour in response to a change in external } \\
\text { environment }\end{array}$ & No & Yes \\
\hline & Influence of stakeholders on decision making in SE & Yes & Yes \\
\hline & Stakeholder engagement practices & Yes & Yes \\
\hline \multirow{3}{*}{$\begin{array}{l}\text { Organizational } \\
\text { factors }\end{array}$} & Importance of organizational growth & No & Yes \\
\hline & Importance of innovation in the start-up phase of SE & Yes & Yes \\
\hline & Importance of innovation in current phase & Yes & Yes \\
\hline Group-level & Team work & Yes & Yes \\
\hline \multirow{7}{*}{ Individual } & Employing paid staff & No & Yes \\
\hline & Previous experience in founding a SE & No & Yes \\
\hline & Previous experience in managing SE & No & Yes \\
\hline & Main motivation to work in/ found SE & No & Yes \\
\hline & Satisfaction with professional life in general & No & Yes \\
\hline & Education & No & Yes \\
\hline & Being disabled & No & Yes \\
\hline
\end{tabular}

Note: * For more detailed result on the European pool results please see Aleksic Miric, Petrovic \& Celikovic (2018).

In this paper we studied the determinants of organizational innovativeness within the pool of social enterprises in Serbia. Following the systematization of the innovation drivers into four groups: external environment of the organization, macroorganizational factors, group (team)-level factors and people-related innovation drivers we defined in the section 2 , we make the following conclusions:

\section{External environment}

The influence of external environment is important for innovation in a sense that ISE report being to a higher extent involved in innovation due to changes in the external environment, while NISE report not being involved in innovation to a higher extent due to this same reason. Innovative social organizations also report to be more prone towards developing more diverse network of business relations, and involving stakeholders (Owner/Boards of Directors, employees, suppliers, customers and users, third sector organizations and NGOs, and the community) in their decision-making process more. They are more likely to use collection of feedback, surveys and evaluation of users' satisfaction and social media as stakeholders' engagement practices in comparison with non-innovative ones. Bank loans availability in the start-up phase, and grants from projects during development are connected to innovativeness of social enterprises. These conclusions are true both for Serbia and for the whole European sample. In addition to this, the European pool also reports availability of funding sources and innovation in response to a change in external environment as innovation drivers coming from the external environment. The ISE report to have at disposal the following sources of funding: crowdfunding, microcredit, social investment and private investment with statistically significant difference compared to NISE. In statistically higher percent 
ISE also innovated in response to a change in external environment while NICE in statistically higher percent did not innovate in response to a change in external environment.

\section{Organizational factors}

Among macro-organizational factors, awareness of their social mission, perception of innovation as important element of their doing business at an early stage of organizational development, and orientation towards growth are distinguished as important for organizational innovativeness. The Serbian data pool also confirms the relatedness of awareness of their social mission and perception of innovation as an important element of their doing business at an early stage of organizational development with innovative behaviour of social enterprises. These conclusions are also true for 11 European countries, with an important notion that the EU data sample reports ISE to rate growth as more important in comparison with NISE.

\section{Group-level factors}

Another important characteristic of innovative social enterprises that seems to be influencing innovativeness is trust, as it is significantly higher among team members in ISEs. This is confirmed both in Serbia and the EU datasets.

Individual-level factors

The Serbian data pool reports that individual level factors do not influence innovativeness of social enterprises. The European data pools report just the opposite: education of the founder/manager of a social enterprise and previous personal experience in founding or managing a social enterprise influences innovativeness in a positive manner. Innovation seems to be connected to professional life satisfaction; also, respondents report being more satisfied with professional life in innovative than in non-innovative social enterprises. On the level of people involved, compared to non-innovative organizations, the innovative ones report to hire paid employees to a higher extent.

In summary, exploring Serbian SEs we found that the awareness of their social mission, perception of innovation as important, financing obtained via grant schemes and involvement of owners, the board, customers and NGOs are the most important drivers of innovativeness in Serbian social enterprises. The European pool of explored SEs report additional factors influencing innovativeness such as availability of funding, innovativeness in response to a change in external environment, orientation towards growth, having paid staff, previous experience in founding/managing a social enterprise, motivation to work in / found an SE, professional life satisfaction, education level and being disabled. The most important differences occurred on the individual level of entrepreneur / manager of the SE, which significantly influences innovativeness of social enterprises in explored European sample, while not in the explored sample of Serbian social enterprises.

\section{REFERENCES}

[1] Abrams, L.C., Cross, R., Lesser, E., \& Levin, D.Z. (2003). Nurturing interpersonal trust in knowledgesharing networks. Academy of Management Executive, 17(4), 64-77. DOI: 10.5465/ame.2003.11851845

[2] Aleksic Miric, A., \& Krstic, G. (2016). Development of social enterprises in Serbia: Analysis of factors, actors and relationships. Management: Journal of Sustainable Business and Management Solutions in Emerging Economies, 81, 47-57 Retrieved from

http://www.management.fon.rs/management/e_management_81_english_05.pdf DOI: 10.7595/management.fon.2016.0030

[3] Aleksic Miric, A., Petrovic, M., \& Celikovic, Z. (2018). Understanding innovative behavior of social enterprises. U M. Biggeri, E.Testi, M. Bellucci, R., H. Thomas, R. Persson. (Eds.). Social Entrepreneurship and Social Innovation (Chapter 9). Ecosystems for Inclusion in Europe, Routledge. DOI: 10.4324/9781351239028-9

[4] Alvord, S. H., Brown, L. D. \& Letts, C. W. (2004). Social entrepreneurship and societal transformation: An exploratory study. Journal of Applied Behavioral Science, 40(3), 260-282. DOI: $10.1177 / 0021886304266847$

[5] Austin, J., Stevenson, H. \& Wei-Skillern, J. (2006), Social and Commercial Entrepreneurship: Same, Different, or Both?. Entrepreneurship Theory and Practice, 30, 1-22. DOI: 10.1111/j.15406520.2006.00107.x

[6] Avanti, F. (2009). Innovate we can!. Jakarta: Grasindo

[7] Bellucci, M., Testi, E., Franchi, S., \& Biggeri, M. (2018). Emerging managerial aspects of social entrepreneurship in Europe. In Social Entrepreneurship and Social Innovation (pp. 54-68). Routledge. DOI: $10.4324 / 9781351239028-5$

[8] Betz F. (1998). Managing technological innovation: Competitive advantage from change. Wiley: New York. DOI: $10.1002 / 9780470927564$

[9] Biggeri, M., Testi, E., \& Bellucci, M. (2017). Enabling ecosystems for social enterprises and social innovation: A capability approach perspective. Journal of Human Development and Capabilities, 18(2), 299-306. DOI: 10.1080/19452829.2017.1306690 
[10] Biggeri, M., Testi, E., Bellucci, M., During, R., \& Persson, H. T. R. (Eds.). (2018). Social Entrepreneurship and Social Innovation: Ecosystems for Inclusion in Europe. Routledge. DOI: 10.4324/9781351239028

[11] Brandsen, T., Cattacin, S., Evers, A., \& Zimmer, A. (Eds.). (2016). Social innovations in the urban context. Springer Open. DOI: 10.1007/978-3-319-21551-8

[12] Bryson, A., Dale-Olsen, H., \& Barth, E. (2009). How does innovation affect worker well-being? London School of economics and political science. Retrieved from http://eprints.Ise.ac.uk/27781/1/dp0953.pdf

[13] Choi, N., \& Majumdar, S. (2014). Social entrepreneurship as an essentially contested concept: Opening a new avenue for systematic future research. Journal of Business Venturing, 29(3), 363-376. DOI: 10.1016/j.jbusvent.2013.05.001

[14] Clark, P.A. (1987). Anglo-American Innovation. Walter de Gruyter Berlin. New York DOI: $10.1515 / 9783110857504$

[15] Damanpour, F., \& Gopalakrishnan, S. (1998). Theories of organizational structure and innovation adoption: the role of environmental change. Journal of Engineering and technology management, 15(1), 1-24. DOI: 10.1016/s0923-4748(97)00029-5

[16] Di Domenico, M., Haugh, H. \& Tracey, P. (2010), Social bricolage: Theorizing social value creation in social enterprises. Entrepreneurship Theory and Practice, 34, 681-703. DOI: $10.1111 / \mathrm{j} .1540-6520.2010 .00370 . x$

[17] Doherty, B., Haugh, H. \& Lyon, F. (2014) Social enterprises as hybrid organizations: A review and research agenda. International Journal of Management Reviews, 16(4), 417-436. DOI: 10.1111/ijmr.12028

[18] During, R., Persson, H. T. R., Biggeri, M., Enrico, T., \& Bellucci, M. (2018). Research background, theoretical frameworks, and methodologies for social entrepreneurship. In Social Entrepreneurship and Social Innovation (pp. 13-23). Routledge. DOI: 10.4324/9781351239028-2

[19] Fay, D., Shipton, H., West, M.A., \& Patterson, M. (2015). Teamwork and organizational innovation. Creativity and Innovation Management, 24, 261-277. DOI: 10.1111/caim.12100

[20] Fuchs, P. (2014). Soziale Innovationen durch Sozialunternehmen. Schlüssel zur Lösung gesellschaftlicher Probleme? In Grabbe, C., Obuch, K., \& Zimmer, A. (2018). Social innovation in niches. In Social Entrepreneurship and Social Innovation (pp. 145-163). DOI: 10.4324/9781351239028-10

[21] Garcia-Morales, V. J., Llorens-Montes, F. J., \& Verdú-Jover, A. J. (2006). Antecedents and consequences of organizational innovation and organizational learning in entrepreneurship. Industrial Management \& Data Systems, 106(1), 21-42. DOI: 10.1108/02635570610642940

[22] Gauthier, J., Cohen, D. G., \& Meyer, C. (2018, July). Top Management Team Characteristics and Social Intrapreneurship. In Academy of Management Proceedings(Vol. 2018, No. 1, p. 10923). Briarcliff Manor, NY 10510: Academy of Management. DOI: 10.5465/ambpp.2018.10923abstract

[23] Gundry, L.K., Kickul, J.R., Griffiths, M.D., \& Bacq, S. (2011). Creating social change out of nothing: The role of entrepreneurial bricolage in social entrepreneurs' catalytic innovations. In G. T. Lumpkin, Jerome A. Katz (ed.). Social and Sustainable Entrepreneurship (Advances in Entrepreneurship, Firm Emergence and Growth, Volume 13). Emerald Group Publishing Limited,1 - 24. DOI: 10.1108/S10747540(2011)0000013005

[24] Guth, W., \& Ginsberg, A. (1990). Guest editors' introduction: Corporate entrepreneurship. Strategic Management Journal, 11, 5-15. Retrieved from http://www.jstor.org/stable/2486666

[25] Hart, S.L. \& Sharma, S. (2004) Engaging fringe stakeholders for competitive imagination', Academy of Management Executive, 18 (1), 7-18. DOI: 10.5465/ame.2004.12691227

[26] Hazenberg, R., Bajwa-Patel, M., \& Giroletti, T. (2018). The role of stakeholder networks in shaping the development of social enterprise ecosystems. In Social Entrepreneurship and Social Innovation (pp. 110-126). Routledge. DOI: 10.4324/9781351239028-8

[27] Jansen, J. P., Vera, D. \& Crossan, M. (2009). Strategic leadership for exploration and exploitation: The moderating role of environmental dynamism, Leadership Quarterly, 20(1), 5-18. DOI: 10.1016/j.leaqua.2008.11.008

[28] Jeraj, M., Maric, M., Todorovic, I., Cudanov, M., \& Komazec, S. (2015). . Amfiteatru Economic Journal, 17 (38), 371-389

[29] , J. (2002). Innovation as the core competency of a service organisation: The role of technology, knowledge and networks. European Journal of Innovation Management, 5(1): 18-26. DOI: $10.1108 / 14601060210415144$

[30] Kimberly, J. R., \& Evanisko, M. J. (1981). Organizational innovation: The influence of individual, organizational, and contextual factors on hospital adoption of technological and administrative innovations. Academy of management journal, 24(4), 689-713. DOI: 10.2307/256170

[31] Koellinger, P. (2008). Why are some entrepreneurs more innovative than others? Small Business Economics, 31(1), 21-37. DOI: 10.1007/s11187-008-9107-0

[32] Krstic, G., Aleksic Miric, A. \& Zarkovic, J. (2017). Profile of social entrepreneur in Serbia: Motivation and socio-demographic characteristics. Sociologija, 59 (1), 62-80. ww.sociologija.org/admin/published/2017_59/1/525.pdf DOI: 10.2298/SOC1701062K 
[33] Leadbeater, C. (1997). The Rise of Social Entrepreneur. Blackwell, London.

[34] Lehner, O. M., \&Kansikas, J. (2012). Opportunity recognition in social entrepreneurship: A thematic meta analysis. The Journal of Entrepreneurship, 21(1), 25-58. DOI: 10.1177/097135571102100102

[35] Mulgan, G. (2006). The process of social innovation. Innovations: Technology, Governance, Globalization, 1(2), 145-162. DOI: 10.1162/itgg.2006.1.2.145

[36] Mumford, M. D. \&Moertl, P. (2003). Cases of social innovation: Lessons from two innovations in the 20th century. Creativity Research Journal,15 (2-3), 261-266. DOI: 10.1080/10400419.2003.9651418

[37] OECD. (2016). OECD science, technology and innovation Outlook 2016. OECD. Retrieved from www.oecd.org/sti/Megatrends\%20affecting\%20science, \%20 technology\%20and\%20innovation.pdf.

[38] Pache, A. C. \& Santos, F. (2012). Inside the hybrid organization: selective coupling as a response to competing institutional logics. Academy of Management Journal, 56, 972-1001. DOI: 10.5465/amj.2011.0405

[39] Park, S., Tseng, Y., \& Kim, S. (2015). The impact of innovation on job satisfaction: evidence from US federal agencies. Asian Social Science, 12(1), 274. DOI:10.5539/ass.v12n1p274

[40] Porter, M. E. (1985). Competitive advantage-creating and sustaining superior performance, USA: The Free Press. DOI: 10.1007/978-3-319-54540-0

[41] Rakic, J.Z., Aleksic Miric, A., Lebedinski, L. \& Vladisavljevic, M. (2017). Welfare State and Social Enterprise in Transition: Evidence from Serbia. Voluntas, 28(6), 2423-2448. DOI: 10.1007/s11266-017-9844-2

[42] Renko, M. (2013). Early challenges of nascent social entrepreneurs. Entrepreneurship Theory and Practice, 37, 1045-1069. DOI: 10.1111/j.1540-6520.2012.00522.x

[43] Sanzo-Perez, M. J., Alvarez-Gonzalez, L. I., \& Rey-García, M. (2015). How to encourage social innovations: a resource-based approach. The Service Industries Journal, 35(7-8), 430-447. DOI: 10.1080/02642069.2015.1015517

[44] Schumpeter, J. A. (1934). The theory of economic development. Harvard University Press: Cambridge, Massachusetts. DOI: 10.1007/0-306-48082-4_3

[45] Sharra, R. \& Nyssens, M. (2018). Social innovation: An interdisciplinary and critical review of the concept. Retrieved from https://pdfs.semanticscholar.org/b46a/2f4e83789220bda416fcb8ac01964156e73d.pdf

[46] Simsek, Z., \& Heavey, C. (2011). The mediating role of knowledge-based capital for corporate entrepreneurship effects on performance: A study of small-to medium-sized firms. Strategic Entrepreneurship Journal, 5, 81-100. DOI: 10.1002/sej.108

[47] Sinclair. S., Mazzei, M., Baglioni, S., \& Roy, M.J. (2018). Social innovation, social enterprise, and local public services: Undertaking transformation? Social Policy \& Administration, 52, 1317-1331.

[48] Testi, E., Biggeri, M., Colucci, D., Doni, N., \& Valori, V. (2018). Are decision makers in Social Enterprises more pro-social than their peers? An analysis of production and consumption choices. In Social Entrepreneurship and Social Innovation (pp. 69-95). Routledge.

[49] Thornhill, S. (2006). Knowledge, innovation and firm performance in high- and low-technology regimes. Journal of Business Venturing, 21(5), 687-703.

[50] Tu, C., \& Hwang, S. N. (2013). Innovation and success in micro-enterprises: The role of family and environments. International Proceedings of Economics Development \& Research, 70.

[51] Urbancova, H. (2013). Competitive advantage achievement through innovation and knowledge. Journal of Competitiveness. 5 (1), 82-96.

[52] Wolfe, R. A. (1994). Organizational innovation: Review, critique and suggested research directions. Journal of management studies, 31(3), 405-431. Retrieved from

[53] Zahra, S. A. (1993). Environment, corporate entrepreneurship, and financial performance: a taxonomic approach. Journal of Business Venturing, 8(4), 319-340.

[54] Zahra, S. A., Gedajlovic, E., Neubaum, D. O., \& Shulman, J. M. (2009). A typology of social entrepreneurs: Motives, search processes and ethical challenges. Journal of business venturing, 24(5), 519-532.

[55] Zahra, S. A., Newey, L. R. \& Li, Y. (2014). On the frontiers: The implications of social entrepreneurship for international entrepreneurship. Entrepreneurship Theory and Practice, 38, 137-158.

[56] Zaltman, G., Duncan, R., \& Holbek, J. (1973). Innovations and organizations (Vol. 1973). New York: Wiley.

[57] Zarkovic Rakic, J., Aleksic Miric, A., Lebedinski, L., \& Vladisavljevic, M. (2017). Welfare state and social enterprise in transition: Evidence from Serbia. Voluntas: International Journal of Voluntary and Nonprofit Organizations, 28 (6), 2423-2448 DOli:10.1007/s11266-017-9844-2, Retrieved from https://link.springer.com/content/pdf/10.1007\%2Fs11266-017-9844-2.pdf

Received: 2018-02-05

Revision requested: 2019-04-01 Revised: 2019-04-18 (2 revisions) 


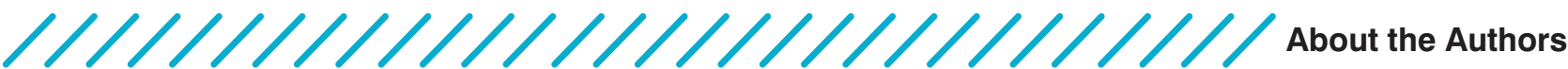

\author{
Ana Aleksić Mirić \\ University of Belgrade, Faculty of Economics, Serbia \\ anaa@ekof.bg.ac.rs
}

Ana Aleksić Mirić is an Associate Professor at the Faculty of Economics, University of Belgrade. She holds a MSci and PhD from the Faculty of Economics at the University of

Belgrade. She has been a visiting scholar at Duke University's Fuqua School of

Business (USA) and Carnegie Mellon University (USA). She has been involved in research projects financed by the European Union, the World Bank Institute, and the Serbian government. These projects emphasized the effects that reforms to the Serbian economy have had on growth, employment, competitive market structure, and the competitiveness of firms. Ana has served as a consultant for both private and public organizations. She also has a rich publishing history, producing individual chapters and articles in several edited collections and scholarly journals.

\section{Marina Petrović \\ University of Belgrade, Faculty of Economics, Serbia marinap@ekof.bg.ac.rs}

Marina Petrović is a Teaching Assistant at the Faculty of Economics, University of

Belgrade. She holds an MSci from the Faculty of Economics at the University of Belgrade. She is currently a PhD candidate in statistics from the Faculty of Economics at the University of Belgrade. She has taken part in research projects financed by USAID,

the World Bank, and the Serbian government. These projects involved statistical analysis of the effects that reforms to the Serbian economy have had on economic growth, the labour market, and education. Her primary research interests are statistics, market research, and online surveys. She has contributed individual chapters and articles to several edited collections and scholarly journals.
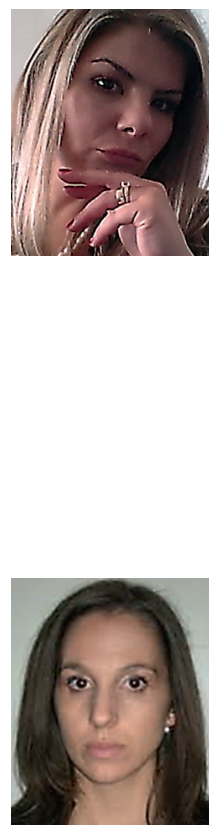

Zorica Aničić

University of Belgrade, Faculty of Economics, Serbia zorica@ekof.bg.ac.rs

Zorica Aničić is a Teaching Assistant at the Faculty of Economics, University of Belgrade. She holds a MSc. from the Faculty of Economics at the University of Belgrade. While working on her MSc., she was hired as a regional pricing analyst by a multinational pharmaceutical company. She is currently a doctoral student in the Faculty of Economics at the University of Belgrade. She has been involved in research projects financed by the European Union, the Serbian government, and several private companies in Serbia. Her research focuses on entrepreneurship, corporate government, financial analysis, and facilities studies. She has served as a consultant for both private- and public-sector organizations, and has had her work published in several scholarly journals.

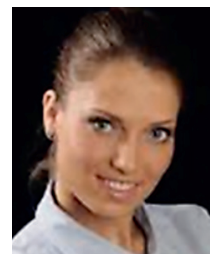

